and death, possibly associated with multidrug-resistant Shigella spp., a review of the national policy for the management of bloody diarrhea is urgently needed.

\section{Acknowledgments}

We thank Darrel Cecil, Temas Ikanofi, Leomeldo Latorre, and Luisa Wanma for their diagnostic support; and Anthony Gomes, Irwin Law, Carmen Aramburu, and Eigil Sorensen for their technical support.

\section{Alexander Rosewell, Rosheila Dagina, Manoj Murhekar, Berry Ropa, Enoch Posanai, Samir Dutta, Ian Barr, Glen Mola, Anthony Zwi, and C. Raina Maclntyre Author affiliations: World Health Organization, Port Moresby, Papua New Guinea (A. Rosewell, M. Murhekar); University of New South Wales, Sydney, New South Wales, Australia (A. Rosewell, A.}

Zwi, C.R. MacIntyre); National Department of Health, Port Moresby (R. Dagina, B. Ropa, E. Posanai); Port Moresby General Hospital, Port Moresby (S. Dutta); World Health Organization Collaborating Center for Reference and Research on Influenza, Melbourne, Victoria, Australia (I. Barr); and University of Papua New Guinea, Port Moresby (G. Mola)

\section{DOI: 10.3201/eid1704.101021}

\section{References}

1. Outbreak of influenza, Madagascar, July-August 2002. Wkly Epidemiol Rec. 2002;77:381-4.

2. Corwin $\mathrm{AL}$, Simanjuntak $\mathrm{CH}$, Ingkokusumo G, Sukri N, Larasati RP, Subianto B, et al. Impact of epidemic influenza A-like acute respiratory illness in a remote jungle highland population in Irian Jaya, Indonesia. Clin Infect Dis. 1998;26:880-8. DOI: $10.1086 / 513917$

3. Sungu M, Sanders R. Influenza virus activity in Papua New Guinea. P N G Med J. 1991;34:199-203.

4. Clemens J, Kotloff K, Kay B. Generic protocol to estimate the burden of Shigella diarrhoea and dysenteric mortality. Geneva: World Health Organization; 1999.
5. Bennish ML, Wojtyniak BJ. Mortality due to shigellosis: community and hospital data. Rev Infect Dis. 1991;13(Suppl 4):S245-51.

6. Kotloff KL, Winickoff JP, Ivanoff B, Clemens JD, Swerdlow DL, Sansonetti PJ, et al. Global burden of Shigella infections: implications for vaccine development and implementation of control strategies. Bull World Health Organ. 1999;77:651-66.

7. Grais RF, Conlan AJK, Ferrari MJ, Djibo A, Le Menach A, Bjørnstad ON, et al. Time is of the essence: exploring a measles outbreak response vaccination in Niamey, Niger. J R Soc Interface. 2008;5:6774. DOI: $10.1098 /$ rsif.2007.1038

8. Situation report-diarrhoeal disease outbreaks in Papua New Guinea. Port Moresby (Papua New Guinea): Surveillance Unit, National Department of Health; 2009.

9. World Health Organization. Guidelines for the control of shigellosis, including epidemics due to Shigella dysenteriae type 1 [2010 May 20]. http://www.who.int/ topics/cholera/publications/shigellosis/ en/index.html

Address for correspondence: Alexander Rosewell, World Health Organization, 4th Floor, AOPI Centre, PO Box 5896, Port Moresby, Papua New Guinea; email: rosewella@wpro. who.int

\title{
Vol. 16, No. 12
}

An online Technical Appendix was omitted from the article Mycobacterium tuberculosis Infection of Domesticated Asian Elephants, Thailand (T. Angkawanish, et al.). The article has been corrected online (http://www.cdc.gov/ eid/content/16/12/1949.htm).

\section{Get the content you want delivered to your inbox.

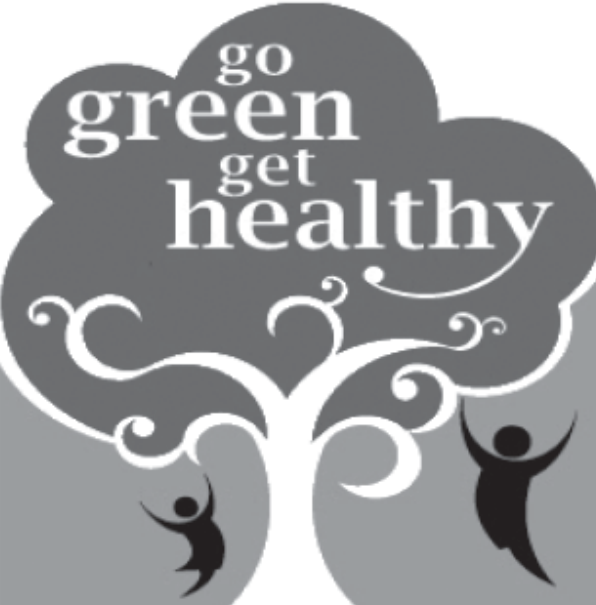 \\ Table of Contents \\ Podcasts \\ Ahead of Print Articles \\ Medscape CME" \\ Specialized Content \\ Online subscription: www.cdc.gov/ncidod/eid/subscrib.htm}

